\title{
'Sie ist so ferne ihm, und doch so nah': Reciprocity and Exchange in the Lyric Poetry of Sophie Mereau
}

Reciprocity was a ubiquitous theme around 1800. From the Idealist concern with overcoming Kantian dualism, to the theory and practice of Geselligkeit, notions of reciprocity in all its forms underpinned the activity of the German intelligentsia. Given that it was so much in the air, it is reasonable to suppose that it might also feature in the work of less canonical figures - including women, even if it is not articulated in strictly philosophical terms in their output. In what follows, I shall explore the theme, which appears in various guises, in writing by Sophie Mereau. I will focus particularly on her poetry, which has received less attention than her other writing, and I shall relate her work to that of other poets. Exchange is, moreover, a particularly dynamic contextual issue where women writers in the Goethezeit are concerned, and it is there that our discussion will begin.

First, though, a little background to our central figure. Sophie Schubart married the librarian and professor of law Friedrich Ernst Carl Mereau primarily because of the access she would gain thereby to the intellectual scene in Jena and Weimar. She was a consummate networker, and her considerable personal magnetism ensured that she was noticed: she was, for example, the only woman to attend Fichte's lectures in Jena in 1793. Mereau also achieved considerable recognition in the 'virtual' public sphere. Unlike many of her peers, female or male, she frequently published under her own name. ${ }^{1}$ The patronage of Friedrich Schiller helped to secure her relatively high profile at the time: her first published poem appeared in the Thalia in 1791, followed by other works in the Musenalmanach and the Horen in subsequent years. ${ }^{2}$ Her verse attracted the attention of composers, with settings by, among others, Reichardt, Zelter, and even the young Beethoven. ${ }^{3}$ With the almanac Kalathiskos, which she founded in 1801, she sought to provide a new vehicle for women writers with herself as the lodestar, of course. The publication (which, regrettably, ran to only two issues) also pushed boundaries: the biographical essay that Mereau included on the seventeenth-century French writer Ninon de Lenclos and sexual equality, for example, has been described as 'stunningly provocative'. ${ }^{4}$ At the same time, her work evinces a desire to match skills with her male peers. In a recent study, Adrian Daub has brought into relief Mereau's engagement with contemporary philosophy, identifying in Blüthenalter der Empfindung a response to an early formulation of Fichte's

I would like to express my gratitude to my colleagues: to the EGS for a lively and supportive discussion of the paper, and in particular to John Guthrie and Daniel Wilson, who so helpfully read and commented upon earlier drafts.

\footnotetext{
${ }^{1}$ Even though her early novel, Das Blüthenalter der Empfindung, appeared anonymously at first, her decision to sign the preface 'Die Verfasserin' was a gesture of defiance: for the sense that their work would be taken less seriously should their gender be discovered was, of course, one of the main reasons why so many women writers concealed their identity. See Katharina von Hammerstein's commentary to her critical edition of Mereau's works: Ein Glück, das keine Wirklichkeit umspannt. Gedichte und Erzählungen, Munich, 1996, pp. 231-58 (p. 231).

${ }^{2}$ Schiller's attitude to women writers was notoriously ambivalent. Yet the commonplace that he only condescended to include writing by women in the Horen when, indeed because the journal had already started to fail, has been contested: see Janet Besserer Holmgren, The women writers in Schiller's Horen: patrons, petticoats, and the promotion of Weimar Classicism, Newark, 2007. Schiller's early and consistent support for Mereau is strong evidence for this different viewpoint.

${ }^{3}$ See Beate Agnes Schmidt, 'Kunst und Geselligkeit: Sophie Mereaus Lyrik im Kontext der Liedkultur um 1800', in: Sophie Mereau: Verbindungslinien in Zeit und Raum, ed. by Katharina von Hammerstein and Katrin Horn, Heidelberg, 2008, pp. 377-96.

${ }^{4}$ Daniel Purdy, 'Sophie Mereau's Authorial Masquerades and the Subversion of Romantic Poesie', in: Women in German Yearbook, 13 (1997), 29-49 (p. 32).
} 
Wissenschaftslehre. ${ }^{5}$ This is significant because philosophy, perhaps more than any other sphere of intellectual endeavour, was considered very much male territory in this period. ${ }^{6}$ Other critics have also engaged with Mereau's work, traditionally considered rather lightweight, at a greater level of sophistication than before, highlighting the self-awareness and experimental nature of her writing. ${ }^{7}$ In sum, Mereau's work straddles the activity of the female and male intelligentsia - insofar as they can be understood as distinct phenomena.

Feminist scholarship long emphasised the exclusion of women from the literary mainstream, both during the Goethezeit itself and in the process of canonization. Women's education was stunted, meaning that many of them did not have the same range of reference as men. ${ }^{8}$ Their writing often reflected the preoccupations bred by lives that were, in most cases, profoundly different from those of men. Moreover, there was around 1800 a proliferation of normative, in some cases proscriptive, commentaries on 'appropriate' themes and forms for women writers. ${ }^{9}$ In 1804, after the publication of her first collection of poems, Gedichte und Phantasien, Brentano wrote in a now infamous letter to Karoline von Günderrode:

Das einzige, was man der ganzen Sammlung Böses vorwerfen könnte, wäre, daß sie zwischen dem Männlichen und Weiblichen schwebt, und hier und da nicht genug Gedichten, sondern sehr gelungen aufgegebenen Exerzitien oder Ausarbeitungen gleicht. ${ }^{10}$

From Brentano's pen, this is mild criticism; indeed, he is quite effusive elsewhere with his praise for Günderrode. He had kept his real disdain for the woman he married in 1803 - Sophie Mereau: 'Es ist für ein Weib sehr gefährlich zu dichten, noch gefährlicher einen Musenalmanach herauszugeben'. ${ }^{11}$ Further on in that letter, Brenatno half-repents, writing: 'Meinen [sic] Scherz über die Schriftstellereien der Weiber kränkt sie $[$ sic] gewiß nicht, ich habe nie den mindesten Autorstolz in Ihnen bemerkt'. ${ }^{12}$ Mereau, however, gives as good as she gets, replying archly: 'Für die Zukunft werde ich wenigstens mit Versemachen meine Zeit nicht mehr verschwenden, und wenn ich mich ja genötigt sehen sollte, zu schreiben, nur gute moralische oder Kochbücher zu verfertigen suchen. ${ }^{13}$ There are, then, compelling reasons for viewing writing by women as a field that is best approached with sensitivity to the often unfavourable socio-historical circumstances surrounding their work.

\footnotetext{
5 Adrian Daub, Uncivil Unions: the Metaphysics of Marriage in German Idealism and Romanticism, Chicago, 2012, pp. 207-239 (esp. pp. 207-212).

${ }^{6}$ Katharina von Hammerstein also gives a useful account of Mereau's forays into 'masculine' territory: Mereau, Gedichte und Erzählungen, p. 239.

${ }^{7}$ See Todd Kontje, Women, the Novel and the German Nation 1771-1871: Domestic Fiction in the Fatherland, Cambridge, 1998 (esp. p. 76), and Purdy, 'Sophie Mereau's Authorial Masquerades' (esp. pp. 33-35). Also Kontje, 'Sophie Mereau: Topographies of Freedom and Constraint', and Purdy, 'Plucking the Strings of Desire: Abstraction and Sensuality in Sophie Mereau's "Bildungsgeschichte", in: Sophie Mereau: Verbindungslinien in Zeit und Raum, pp. 99-116 and pp. 145-61.

${ }^{8}$ See e.g. Kevin Hilliard, 'Religious and Secular Poetry and Epic, 1700-1780', in: German Literature of the Eighteenth Century: Enlightenment and Sensibility, ed. by Barbara Becker-Cantarino, Rochester, NY, 2005, 105-130 (pp. 115-16).

${ }^{9}$ See e. g. Helen Fronius's study Women and Literature in the Goethe Era (1770-1820): Determined Dilettantes, Oxford, 2007, pp. 53-93, and Barbara Becker-Cantarino's article “"Gender Censorship": On Literary Production in German Romanticism', translated by Jeanette Clausen, in: Women in German Yearbook, 11 (1995), 81-97.

${ }^{10}$ Clemens Brentano, Sämtliche Werke und Briefe: Historisch-kritische Ausgabe veranstaltet vom Freien Deutschen Hochstift, ed. by Jürgen Behrens et al., Stuttgart, 1975-, XXXI (1991), p. 328.

${ }^{11}$ Brentano, Sämtliche Werke, XXXI, p. 15.

${ }^{12}$ Brentano, Sämtliche Werke, XXXI, p. 17.

${ }^{13}$ Lebe der Liebe und liebe das Leben: Der Brefwechsel von Sophie Mereau und Clemens Brentano, ed. by Dagmar von Gersdorff, Frankfurt am Main, 1981, p. 116.
} 
Yet, more recently, a different concern has gained traction among critics: namely, that an unqualified focus on the 'otherness' of women writers could risk reinforcing the very marginalization against which some of them battled. ${ }^{14}$ Anne Fleig, for example, contends that, in research on writing by women, '[t]he restrictive reference to femininity or to a female identity must be relinquished and its problems exposed. It is necessary to analyse all issues articulated in the texts and to relate them to contemporary discourses, including men's texts. ${ }^{15}$ In addition, more and more scholars have questioned whether the relegation of women to the realm of the private really was absolute, and to emphasise instead the opportunities for participation in the public sphere - opportunities, often, that women created themselves. ${ }^{16}$ This revisionism has implications for our understanding of the literary landscape: if women were more active in the 'embodied' public sphere than was previously thought, if they had a greater stake in social interaction beyond the purely domestic, then it seems likely that their writing will also be more tightly enmeshed in the 'virtual' public sphere that is the world of letters. To be sure, Mereau's biography attests to a degree of participation which was unusual even when the findings of revisionist social historians are taken into account; but this makes her a good candidate to test the limitations, as well as the possibilities, of an approach based on the assumption that exchange, rather than separation, characterized women's involvement in the literary scene.

Mereau's poem 'An Goethe' (1802), though by no means overtly provocative, can be read as a subtle formulation of literary ambition.

Oft, wenn ich still, mit seligem Vergnügen,

In Deiner Feder schöpferischen Zügen,

Den hohen Geist, das wundervolle Leben,

Das die Natur dem Liebling hingegeben,

Die Allgewalt, die über das Gewühl

Der Menge, Licht und süße Heiterkeit

Ergießt, wie auf der Fluten wechselnd Spiel,

Der Gott des Lichts die Feuersäle streut,

Wenn ich dies alles, in mich selbst gewandt,

In stiller Seele innig tief empfand,

Da dünkt' es würdig meinem Wunsch' und heilig,

Den Spiegel dieser göttlichen Gedanken

Minutenlang bewegen, leis' und eilig,

Wie Morgenträume leicht vorüber wanken.

So steht an eines großen Sees Gestade,

Des Herrlichen, die Blume bebend da;

Sie ist so ferne ihm, und doch so nah.

In seine Flut neigt sich zum Wellenbade

Der gold'ne Phöbus; mit bewegter Brust

Schaut Phöbe, zögernd, sich, und alle Sterne,

\footnotetext{
${ }^{14}$ See, for example, Elizabeth Eger, 'Fashioning a Female Canon: Eighteenth-Century Women Poets and the Politics of the Anthology', in: Women's Poetry in the Enlightenment: The Making of a Canon, 1730-1820, ed. by Isobel Armstrong and Virginia Blain, Basingstoke, 1999, pp. 201-15.

${ }^{15}$ Anne Fleig, 'Forgotten Women Writers? Reflections on the Current State and Future Prospects of Gender Studies', in: German Women's Writing of the Eighteenth and Nineteenth Centuries: Future Directions in Feminist Criticism, Oxford, 2011, pp. 16-26 (p. 21).

${ }^{16}$ Julia Di Bartolo engages usefully with these developments in her study Selbstbestimmtes Leben um 1800. Sophie Mereau, Johanna Schopenhauer und Henriette von Egolffstein in Weimar-Jena, Heidelberg, 2008. See esp. pp. 11-12 for an overview of research in this area.
} 
Sehn in dem reinen Spiegel, voller Lust,

Ihr treues Bild aus ungemeßner Ferne.

Es neigt die Blume sich, in ihm ihr Bild zu sehn,

Auf einen Augenblick - um froher zu vergehn. ${ }^{17}$

'An Goethe' appears to be a straightforward paean: the great poet is celebrated in the highest terms, and the lyric I is ostensibly a self-effacing one. Yet the second strophe in particular has an additional dynamic; very subtly, it advances a claim to parity - not with the dedicatee, but with the rest of the community. In that second strophe, the poem moves into allegory: the 'ich' of the first strophe is replaced by 'die Blume', the poetic voice identifying itself, arguably, as female. The lake by which the flower is positioned represents (as I understand it) the reflective and fluid depths of the work of the dedicatee, who himself regards and illumines his own work from on high ('Phöbus', the god of light and poetry, to whom Goethe was indeed often compared by his contemporaries). It is less clear whom 'Phöbe' represents, but it is interesting that Mereau should have chosen names which allow direct masculine and feminine counterparts - not Apollo and Luna or Diana, or Artemis or Selene. Finally, given the title of the poem and the structure of the allegory, we can conjecture that the 'Sterne' might allude to the luminaries of the intellectual scene in Weimar and Jena. After the sun-god has dipped into the lake, the rest of the company incline towards and find themselves ('ihr treues Bild') in it; and so does the flower. The poetic voice does not make aggrandizing claims for itself; indeed, by casting itself as a trembling presence at the edge of the lake, it appears to reinforce its own marginality. But it shares in the experience of the whole company and is, in that respect, no different from them.

The poet also conceives of herself as in a position of exchange with the one being eulogized. The line 'Sie ist so ferne ihm, und doch so nah' first establishes a respectful distance between the flower and the lake of poetry, before asserting their proximity. Moreover, the motif of the mirror symbolizes the process of inspiration. In the previous stanza, reading Goethe's poetry is compared to manipulating the mirror of his ideas - 'Den Spiegel dieser göttlichen Gedanken / Minutenlang bewegen': an active and reflective type of reading, in short. At the poem's close, it is the flowerpoet's own image which is returned. Given that this comes at the end of a poem of her own creation, it could be read as an image not just of her preoccupations as a reader, but of her possibilities as a poet, guided and inspired by greatness. The final moment - 'Es neigt die Blume sich, in ihm ihr Bild zu sehn' - is immediately qualified by the word 'vergehen'; but the suggestion is nonetheless that this little flower dares to look the great lake in the face. Thus the poem is both a eulogy, and the subtlest assertion of intellectual relevance - no more, but also no less. This is made more palatable for readers around 1800 - indeed, it is almost eclipsed - by the modest and gentle (that is, 'feminine') tone that much of the vocabulary works, self-consciously, to create. The motif of the quivering flower allows the poet to slip in images of proximity and reciprocity, as it were by stealth.

Yet the fact that the poet still opts for what has been called 'pseudonymes Verhalten' ${ }^{18}$ could be seen to diminish the challenge to marginalization, even as it poses it. Certainly, as an expression of

\footnotetext{
${ }^{17}$ Mereau, Gedichte und Erzählungen, p. 35.

${ }^{18}$ Susanne Kord coins the term to describe the tactic, common in this period, whereby women adopt a style or manner, or write a preface, which conforms outwardly to contemporary notions of femininity, and which allows them to continue their literary and intellectual exploration under the radar, as it were. See Ein Blick hinter die Kulissen: Deutschsprachige Dramatikerinnen im 18. und 19. Jahrhundert, Stuttgart, 1992, p. 17. In respect of the lyric poet Philippine Gatterer, Gesa Dane likewise observes that: 'The modesty topos [...] which dominates both the lyric and autobiographical testimony of this writer, [should be taken as a stylisation]'. 'Women writers and Romanticism', in The Cambridge Companion to German Romanticism, Cambridge, 2006, pp. $133-46$ (p. 138).
} 
ambition, 'An Goethe' is pitched less directly than Karoline von Günderrode's 1806 poem 'Zueignung', the opening poem to her final collection Melete:

Ich habe Dir in ernsten stillen Stunden,

Betrachtungsvoll in heil'ger Einsamkeit,

Die Blumen dieser und vergangner Zeit,

Die mir erblüht, zu einem Kranz gewunden.

Von Dir, ich weiß es, wird der Sinn empfunden,

Der in des Blüthenkelchs Verschwiegenheit

Nur sichtbar wird dem Auge, das geweiht

Im Farbenspiel den stillen Geist gefunden.

Es flechten Mädchen so im Orient

Den bunten Kranz; daß Vielen er gefalle,

Wetteifern unter sich die Blumen alle.

Doch Einer ihren tiefern Sinn erkennt,

Ihm sind Symbole sie nur, äußere Zeichen;

Sie reden ihm, obgleich sie alle schweigen. ${ }^{19}$

Here, as in the second verse of 'An Goethe', the central imagery is floral. Flowers are a wellestablished symbol for poetry, but, owing to the pervasive cultural identification of women with flowers - in the modern world, at least - such imagery acquires an additional charge in the hands of a female writer. In the work of a poet known for her 'masculine' aspirations, it is particularly striking. In the image of winding a floral wreath, the poetic voice chooses a typically, almost stereotypically, 'feminine' pastime to describe its own activity. Yet the isolation described, indeed coveted, in the poem is not that of a person hidden away in the realm of the domestic. It is the solitude, rather, of one who has moved beyond the banalities of the public sphere to a new and sovereign type of privacy. In Günderrode's poem, 'Einsamkeit' is less the result of marginalization by others than the desired outcome as the poet herself pulls the strings of inclusion and exclusion.

Both 'Zueignung' and 'An Goethe' open with their poets relishing the solitude of reading, or writing, poetry: 'in ernsten stillen Stunden', 'Oft wenn ich still, mit seligem Vergnügen'. In 'Zueignung' in particular, that 'heil'ge Einsamkeit' is part of the claim to singularity advanced by the poem as a whole. It is addressed to an adept: the words 'Verschwiegenheit', 'geweiht', 'erkennt', all express the conviction that the works in this collection, this 'wreath', are intelligible only to the reader of peculiar discernment. For the author of Melete, it is in silence and seclusion ('de[r] stille Geist'), away from the noisy throng of the commonplace, the 'Viele', that these poems truly sound, and it is in the understanding of that rare initiate that they find community: 'Sie reden ihm, obgleich sie alle schweigen'. The poet claims to have moved beyond ordinary participation to exchange of a far more specialized type. Here Günderrode is in the company of others who seek to define an elite readership: of Klopstock, who addresses his readers as '[I]hr wenigen Edlen' in the opening canto's invocation in Der Messias, and of Goethe, whose poem 'Selige Sehnsucht' of 1815 plays, in a manner not unlike 'Zueignung', with notions of elitism, of reciprocity in solitude, and of radiance in what seems to be effacement. An element of elitism is present in Mereau's poem too: the poet, as we have seen, aligns

\footnotetext{
${ }^{19}$ Karoline von Günderrode, Sämtliche Werke und ausgewählte Studien: Historisch-kritische Ausgabe, ed. by Walter Morgenthaler, Basel, 1990-91, I (1990), p. 318.
} 
herself with the most august company, and the poetry that she reads places her beyond 'das Gewühl der Menge' (first strophe). Yet, although 'An Goethe' hints, as we saw, at the creative potential of its poet, the focus is still on reading; in 'Zueignung', by contrast, the writer puts her own work squarely in the foreground. Mereau is considerably more than the 'Verfasserin anmutiger Frauenpoesien', a mould into which she has often been cast precisely in order to highlight Günderrode's uniqueness; ${ }^{20}$ but there can be no denying that 'Zueignung' is a more direct, less equivocal, bid for power.

Günderrode's poem may be a claim to artistic singularity, but it is, of course, also part of a widespread literary trend: the so-called 'Sonettenwut'. This was followed by both men and women, and the momentum for it was provided in Germany by August Wilhelm Schlegel (though there was a parallel revival in England). At the centre of one of Mereau's sonnets, 'Maria, von Raffael' (1805), we find reciprocity of a different kind from the intellectual participation explored in 'An Goethe'. It describes a heavenly process of recognition, which is set in train by the radiance of the Madonna and has the potential to enfold and redeem mortals too. 'Maria, von Raffael' also resonates strongly, in form and content, with a number of pieces composed by other poets in the preceding years; and it is a useful example of how one might plot relationships between different writers, female and male.

Sie steigt empor! Die Himmelskönigin

Aus blauen Wolken Engelshäupter quellen,

Der Himmel selbst will sich vor ihr erhellen,

Vor ihres Auges hohem, mildem Sinn!

Fest blickt das Kind in jene Strahlen hin,

Die aus dem Himmel ihm entgegen schwellen,

Den Vater sucht es in des Glanzes Wellen,

- Dem Höchsten ist das Höchste nur Gewinn.

O Mutter! die geliebt mit festem Glauben,

O göttlich Kind! das bei dem tiefsten Schmerz,

Wie bei der größten Hoheit kindlich bliebe,

Das willig trug den tiefsten Schmerz der Liebe,

Mit eurem Bilde füllet ganz mein Herz,

Dann kann mir nichts der Himmel rauben. ${ }^{21}$

The poem forms part of another literary trend besides the 'Sonettenwut'. The acquisition of Raphael's Sistine Madonna for the royal collection at Dresden in 1754 was a major cultural moment, given additional resonance by Winckelmann's celebration of the work in his Geschichte der Kunst des Altertums. The writing of poems on the theme became a minor fashion, with contributors ranging from August Wilhlem Schlegel to Friedrich Hebbel. Friedericke Brun's 'Die himmelfahrende Madonna Raphaels in Dresden' of $1803^{22}$ opens with the same idea as Mereau's sonnet,

\footnotetext{
${ }^{20}$ See Dagmar von Gersdorff, 'Die Erde ist mir Heimat nicht geworden': Das Leben der Karoline von Günderrode, Frankfurt am Main, 2006, p. 144.

${ }^{21}$ See Barbara Evers, Frauenlyrik um 1800: Studien zu Geidchtbeiträgen in Almanachen und Tagebüchern der Romantik und Biedermeierzeit, Bochum, 1991, p. 284. I am indebted here to the appendix, compiled by Evers, of facsimiles of poems by women as printed in various journals and almanacs.

${ }^{22}$ Mereau, Gedichte und Erzählungen, pp. 44-45.
} 
'emporsteigen'. ${ }^{23}$ Beyond this, the poems are quite different: each stage of Brun's longer paean is rooted in a detail from the painting, whereas the condensed form of the sonnet almost forces its poet to be selective, and to move more swiftly into abstraction. Mereau has absorbed Schlegel's new mandates for the sonnet: iambic pentameter in place of the alexandrine favoured in the seventeenth century, before the sonnet fell out of fashion, and (mostly) feminine rhymes. But so has Henriette Schubart, Mereau's own sister, in her Madonna-poem, 'Marias Himmelfahrt', published in the Musen-Almanach in $1803 .{ }^{24}$ Although this sonnet is not specifically dedicated to the Sistine Madonna, it bears a number of similarities with Mereau's 'Maria von Raffael': in each case, light figures strongly in the octave, while the sestet is concerned with mother and child, and with redemption from suffering. Mereau's poem is more subtle than Schubart's, however. The differences between the two pieces become clearer when two sonnets from 1801 by Clemens Brentano on the Madonna theme are brought into the comparison. As with Schubart's sonnet, 'Annonciatens Bild' and 'Mariens Bild' ${ }^{25}$ are not about the Sistine Madonna. They are portraits of a little Italian girl and of Brentano's sister Meline respectively; but they are infused with Catholic imagery, and the young women are clearly cast as Madonna-figures.

It is in the lines concerned with light that Mereau's poem begins to resonate with those of Brentano. Schubart has the light describe a circling motion: 'Welch goldner Glanz sinkt aus der Höhe nieder? / Welch eine Lichtgestalt dringt dort empor?' Yet, by comparison with the flux that Mereau establishes, the movement of light in Schubart's sonnet seems rather heavy and laboured. The straightforward movements down from and up to heaven in Schubart's first quatrain are nuanced in Mereau's version, with the notion of heaven itself wishing to become brighter in response to the gaze of the Virgin. This triggers multiple exchanges in the next quatrain: the rays which shine out, as it were in praise of the mother, draw the attention of her child, and seem to intensify further and further ('des Glanzes Wellen') as he seeks in them his father. Thus a relationship of mutual reinforcement is established between the light of the heavens and the sight of the mother's sacred eyes. Cognates of these features can be observed in Brentano's sonnets. In the first tercet of 'Mariens Bild', light and sight are again conflated in the words 'sehen linde Sonnenstrahlen'. Indeed, the addition of 'Durchs Fenster' at the beginning and 'heller malen' at the end of the image render this a more tensile mise-enabyme than we find in Mereau. In 'Annonciatens Bild', as in Mereau's octave, the light seems to intensify line on line. This culminates in the peacock, which illumines and is illumined, but the oranges, too, are invested with a subtle radiance that contributes to the progressive heightening. Yet, although the movements of light are prefaced in Brentano's sonnet by a mention of the gaze of the Mary-figure ('ihre Blicke', in line three), there is no equivalent to the reactive process described by Mereau with the words 'Der Himmel will sich selbst vor ihr erhellen'. Brentano's Madonna-figures may be positioned at the centre of the situation described, but they are not central to its causality: they are much more passive. Through her radiance, Mereau's Madonna kindles a process of mutual reflection and illumination; and inclusion in that web of light will, the poet anticipates, negate, or at least contain, loss ('Da kann mir nichts der Himmel rauben').

In Mereau's sonnet, then, the quality of sublime gentleness usually associated with Maria is invested with a subtle, but powerful dynamism. The female figure is neither dominant nor marginal, casting instead a loving glow which at once soothes and animates her fellows. This is a pattern which

\footnotetext{
${ }^{23}$ In an article on sixty-four poems about the Sistene Madonna, Gisbert Kranz posits 'emporsteigen' as a mark of originality: for, in deliberate contradistinction to other poems of this sub-genre, it moves the gaze of the Madonna away from 'die Menschenerde' and towards 'den höchsten Himmel'. See 'Gedichte über die Sixtinische Madonna', in Zeitschrift für Kunstgeschichte, 44 (1981), 159-170 (p. 165). But he attributes this innovation to Mereau, whereas in fact Brun's poem comes first.

${ }^{24}$ See the facsimile in Evers, Frauenlyrik um 1800, p. 320.

${ }^{25}$ Brentano, Sämtliche Werke, I, pp. 137-38.
} 
Katharina von Hammerstein perceives throughout Mereau's eeuvre: '[Sie erklärt] doch die Liebe weder zur einzigen Domäne der Frau noch zu einem weiblichen Monopol. ${ }^{26}$ Traditional polarities are overcome, Hammerstein continues, with love as much the province of male figures, and female figures characterized by their energy and drive. Traces of this attitude, then, are discernible even in a devotional poem such as 'Maria, von Raffael'. But would we read this and the preceding poems differently if we did not know that their author was a woman, and one of proto-feminist convictions at that? Is there still a danger that, to recall Anne Fleig's words, such references to femininity or to a female identity might on some level be restricting our analysis, as well as feeding it? In the final section of my discussion, I shall attempt a more 'gender-neutral' reading of two further poems, remaining mindful of the possibility that ' $[\mathrm{t}]$ o not represent difference is as important a strategy as to foreground it'. ${ }^{27}$

The relationship between humanity and nature is a fixture of the poetry and thought of the Goethezeit, and so too it occupies a prominent place in Mereau's work. One of her most successful nature poems, 'Frühling', was recommended by Schiller to Reichardt, whose setting was published alongside the poem in the Musen-Almanach für das Jahr $1796 .{ }^{28}$ Even if it is less sophisticated in formal terms, it is, in its ecstatic mood and vocabulary, its apparently unswerving confidence in the reciprocal embrace of nature and humankind, strongly reminiscent of Goethe's 'Ganymed', as these extracts demonstrate:

In ein Meer von süßer Lust versenket, wallt die Seele auf und ab, stürzt, von frohen Ahndungen getränket, sich im Taumel des Gefühls hinab.

\section{$[\ldots]$}

Sind wir nicht aus Einem Stoff gewoben?

Hat der Geist, der mächtig sie durchdrang, nicht auch mir das Herz emporgehoben? tönt er nicht in meiner Leier Klang? ${ }^{29}$

The sense of being drenched with nature's life-force, of unconditional communion with its spirit, is qualified, however, in two poems written in 1800. 'An einen Baum am Spalier', one of Mereau's most famous poems, forms a radical contradiction with the sentiments of 'Frühling', whilst 'Natur' falls somewhere between the two.

This latter poem (which is too long to print in full here) appears in many respects to echo 'Frühling:

Ein Segensstrom wallt durch die blauen Lüfte;

Dem Hain entrauscht die frohste Symphonie.

Vom Liebeshauch des Frühlings sanft bezwungen,

zu neuer Wirksamkeit emporgedrungen,

eint alles sich zu süßer Harmonie.

\footnotetext{
${ }^{26}$ In: Mereau, Gedichte und Erzählungen, p. 245.

${ }^{27}$ Purdy, 'Plucking the Strings of Desire', p. 146.

${ }^{28}$ Mereau, Hammerstein, Gedichte und Erzählungen, p. 268.

${ }^{29}$ Mereau, Hammerstein, Gedichte und Erzählungen, pp. 22-23.
} 
Ich stimme mit in deine Jubelchöre,

Natur; ich störe deine Feier nicht.

Durch dich bin ich auf ewig dir geboren,

froh hab' ich ew'ge Liebe dir geschworen;

und wehe dem, der diese Bande bricht! $!^{30}$

All seems straightforward, the 'süße Harmonie' of the opening stanza chiming with the 'heil'ge Sympathie' of the penultimate strophe of 'Frühling'. Yet it is striking that this harmonious symphony is observed from a distance: there is no mention of a human presence in the entire first verse. True, this is achieved at the beginning of the second, with the lyric 'I' seeming to make a bold entrance; but it immediately qualifies its own presence: 'ich störe deine Feier nicht'. This sows a seed of doubt, implying that there might be some distance, or at least difference, between the natural world and the poet, even as the poet claims to be joining nature's 'Jubelchöre'. This move in turn is countered with a new affirmation of the unity of nature and humankind, 'Durch dich bin ich auf ewig dir geboren', the doubling of the second person pronoun generating additional weight; yet the stanza ends with a return to the vulnerability of that bond: 'wehe dem, der diese Bande bricht!' This rhythm of alternating doubt and affirmation is replicated throughout the poem. Over and over, human woes and inadequacies are pitted against nature's beautiful and sanguine energy. Each time, a resolution is found, and the poem ends with an unqualified image of healing and communion:

Hier fühl' ich mich, von allem Gram entladen, entflammt, durchbebt von neuer Lebenslust.

Die Welt verheißt, mich wieder zu beglücken; ich sinke still mit seligem Entzücken,

Natur, geheilt an deine Mutterbrust.

Yet human deficiencies resurface with such frequency that they threaten to engulf the poem, and, however persistently reconciliation is found, the contrast between human existence and the natural world becomes ever more marked. This is, perhaps despite appearances, a rather different poem from 'Frühling'; and if the poet struggles to contain doubt in 'Natur', it pervades 'An einen Baum am Spalier'.

Armer Baum! - an deiner kalten Mauer

fest gebunden, stehst du traurig da,

fühlest kaum den Zephir, der mit süßem Schauer

in den Blättern freier Bäume weilt

und bei deinen leicht vorübereilt.

O! dein Anblick geht mir nah!

und die bilderreiche Phantasie

stellt mit ihrer flüchtigen Magie

eine menschliche Gestalt schnell vor mich hin,

die, auf ewig von dem freien Sinn

der Natur entfernt, ein fremder Drang

auch wie dich in steife Formen zwang. ${ }^{31}$

\footnotetext{
${ }^{30}$ Mereau, Hammerstein, Gedichte und Erzählungen, pp. 33-34.

${ }^{31}$ Mereau, Hammerstein, Gedichte und Erzählungen, p. 31.
} 
The force of the closing three lines, above all the words 'auf ewig', is all the greater when this poem is read alongside the other two. The piece is fairly atypical of Mereau's poetic æeuvre. Not even 'Natur' is this dejected, and many of her other poems are in a similar vein to 'Frühling'; moreover, her experimentation with the sonnet in the years after this poem suggests a renewed willingness to push 'stiff forms' into elasticity, and to exploit their reflective potential. 'An einen Baum am Spalier' is formally one of Mereau's most interesting poems. It is much slighter than many of her earlier works a sigh, almost, but a powerful one. Its prosy quality (above all the irregular rhythms) perhaps reflects a poverty of aspiration, in line with the bleakness of the scene described; yet it could equally represent a rejection, in verse at least, of 'steife Formen'. Similarly, the resolution of the rhyme scheme into couplets in the second half after the indecision of the first could either be read as an attempt to introduce harmony into this despondent situation (even 'Natur', for all its doubting, has a near-perfect, regular rhyme-scheme); or, conversely, it could be understood as an instantiation of those 'stiff forms' with which the poem ends. These ambiguities are, I think, not to be resolved: rather, they are the formal expression of the doubt which pervades the poem.

For it is, it seems, the form-giving urge which actively disrupts communion. The only equivalent in this poem to the lyre through which, in 'Frühling', nature's spirit sounds, is the poet's 'bilderreiche Phantasie' - and this only furnishes an image of separation. Humanity has been turned against itself, and forced into barren artificiality. The gulf between humanity, above all its 'art', and nature is deepened by the opening image: that is, nature alienated from itself by the force of human intervention, implied by the trellis. Just as, in the mid-1770s, Goethe produces both the ecstasy of Ganymed and the despondency of Faust in 'Nacht', so, at the end of the 1790s, an element of vacillation in her treatment of humanity's relationship with nature can be detected. The sense of constriction evoked in 'An einen Baum am Spalier' is the more powerful because of the apparent confidence, radiated by so many of her other works, in the possibility of overcoming dualism of all types, of achieving reciprocity. We can only speculate on the cause of the apparent deterioration in mood between 'Frühling' and 'An einen Baum am Spalier'; but there is a telling hint of hesitation in Anthony J. Harper's suggestion that '[i]t would be very easy to adopt a biographical approach and read the cold wall as her husband, Professor Mereau, and the tree striving for growth as the poet herself ${ }^{32}$ This would, I think, be a restrictive approach to a poem which, though slight, is rich in philosophical suggestion.

$* * *$

We began with a consideration of the context in which women of the Goethezeit were writing, and with the question of the most effective or appropriate way of reading their work. The relation between 'life' and 'the text', ever a fraught issue for lyric poetry, is particularly so where women writers are concerned. It would be disingenuous in the extreme to pretend that poetic composition around 1800 was a level playing field for men and for women; it is one thing to express ambition, and quite another for that ambition to be recognized and accepted on its own terms. Even Sophie Mereau, who was a relatively successful and privileged writer, faced plenty of resistance to her activity as an intellectual (not least from her second husband, Clemens Brentano, though her first was considerably more supportive), and she is little read today outside feminist circles. On the other hand, scholars in

\footnotetext{
${ }^{32}$ Anthony J. Harper, 'Sophie Mereau (1770-1806): Living to Love and Loving to Live', in: Sappho in the Shadows: Essays on the work of German women poets of the age of Goethe (1749-1832), with translations of their poetry into English, ed. by Anthony J. Harper and Margaret C. Ives, Bern, 2000, pp. 113-144 (p. 118).
} 
increasing numbers have argued convincingly that too exclusive a focus on the disadvantaged position from which women wrote, or simply on the fact of their femaleness, might blind us to other aspects of their work. This is a dilemma without a simple resolution; but it is also an opportunity. Women writers in the Goethezeit should, I believe, find greater representation on university teaching programmes than is currently the case - and not only because they are interesting, or because it is proper that figures who have been unjustly neglected should receive more attention, though both are certainly good and important reasons. Writing by women can open up fresh perspectives, both for students and for their teachers, on familiar themes and canonical works. Above all, the minefield that is writing about writing by women necessitates a reflexive approach, one which engages upfront with the key questions in literary criticism of the last fifty years, from the death (or otherwise) of the author to the history of feminist scholarship. In this respect too, therefore, greater engagement with the field would be an asset to a student's training. This is a fertile area for study at all levels; and perhaps our students will be able to help us decide whether writing by women should be integrated with that of their male peers as a matter of course, or whether it is still best understood as a counter-canon.

Charlotte Lee

Murray Edwards College, University of Cambridge

\begin{abstract}
The marginalization of women writers in the Goethezeit has received considerable attention; yet feminist scholarship has also emphasized the degree of integration into the public sphere which some women achieved. This article considers the lyric poetry of Sophie Mereau in the context of that critical debate, pointing up parallels (and contrasts) with the work of other writers, female and male. Reciprocity is examined here both as a contextual issue and a motif in Mereau's work, and the article highlights the intellectual independence with which she treats themes which were 'in the air' around 1800 .
\end{abstract}

